\title{
The use of augmented reality to educate preschoolers on preventing dental malocclusion
}

\author{
Yulita Salim ${ }^{\mathrm{a}, 1, *}$, Yustisia Puspitasari ${ }^{\mathrm{b}, 2}$, Huzain Azis ${ }^{\mathrm{a}, 3}$, Risnayanti Anas ${ }^{\mathrm{b}, 4}$ \\ ${ }^{a}$ Faculty of Informatics, Universitas Muslim Indonesia, Makassar, Indonesia \\ ${ }^{\mathrm{b}}$ Faculty of Dentistry, Universitas Muslim Indonesia, Makassar, Indonesia \\ ${ }^{1}$ yulita.salim@umi.ac.id; ${ }^{2}$ yustisia.puspitasari@umi.ac.id; ${ }^{3}$ huzain.azis@umi.ac.id; ${ }^{4}$ risnayanti.anas@ gmail.com \\ * corresponding author
}

\begin{tabular}{|c|c|}
\hline ARTICLE INFO & ABSTRACT \\
\hline $\begin{array}{l}\text { Article history } \\
\text { Received August 21, } 2019 \\
\text { Revised September 17, } 2019 \\
\text { Accepted October 4, } 2019 \\
\text { Keywords } \\
\text { Fluoride } \\
\text { Caries } \\
\text { Preschoolers } \\
\text { Augmented Reality (AR) } \\
\text { Malocclusion }\end{array}$ & $\begin{array}{l}\text { According to the World Health Organization (WHO), malocclusion is a } \\
\text { deviation in dentofacial growth or an abnormal relationship between the teeth } \\
\text { of both arches, which results in impaired physical function for sufferers. Causes } \\
\text { of malocclusion include genetic factors, inappropriate growth and development } \\
\text { processes, bad habits of children, and malnutrition. Also, malocclusion can be } \\
\text { caused by a lack of knowledge of children, parents, and guardians of students in } \\
\text { the school environment in maintaining oral health. Nurul Falah Kindergarten, } \\
\text { located in Mamajang District in the middle of Makassar City. However, students } \\
\text { in kindergarten are from the middle to lower economies with a lack of dental } \\
\text { and oral health awareness. According to the principal, some students come with } \\
\text { the condition of not brushing teeth and with cavities. This service activity aims } \\
\text { to help solve the problems faced by teachers in pre-school age students by } \\
\text { providing dental education based on Augmented Reality and Topical } \\
\text { Application Fluor (TAF) as an effort to prevent malocclusion. It is hoped that } \\
\text { through this activity malocclusion prevention can be done through promotive } \\
\text { efforts on dental health. This dental extension will be complemented by the } \\
\text { utilization of information technology advances in the form of android-based } \\
\text { Augmented Reality (AR) technology that is able to visualize an object in } 3 \\
\text { dimensions so that the counseling process becomes more interactive and real. }\end{array}$ \\
\hline
\end{tabular}

This is an open access article under the CC-BY-SA license.

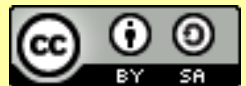

\section{Introduction}

Normal occlusion is a harmonious relationship between teeth and occlusion that requires a balance between teeth, jaw, jaw muscles, temporomandibular joints, and nervous system [1]. Disruption in one of these components will produce an unbalanced relationship called malocclusion [2]. The causes of malocclusion are multifactorial and dentofacial structures caused by genetic and environmental factors [3]. The environment is caused by the habit of not maintaining hygiene during the child's growth and development process [4]. Caries and premature loss or early date of deciduous teeth predispose to the lack of space in the tooth replacement and permanent phase [5].

Prevalence studies of the frequency of premature loss of deciduous teeth reached $15.1-54.26 \%$ [6]. According to the study, primary teeth often experience premature loss of deciduous molars are the teeth of the lower jaw [1]. Premature loss that occurs in primary teeth is caused by caries [7]. Awareness of adults in Indonesia to come to the dentist is less than $7 \%$ and in children around $4 \%$. $72.1 \%$ of Indonesia's population has cavities, and $46.5 \%$ do not treat cavities. The average patient visit is in an excellent condition for treatment, so it can be interpreted that the level of public awareness to seek treatment as early as possible is still lacking. The utilization of dental and oral health services is not only in the form of tooth extraction and dental fillings, but the community must visit at least once every six months. 
This dental extension will utilize Augmented Reality (AR) technology. Augmented Reality is a technology that can combine a 3D object into a real environment using webcam media [8], [9]. The advantage of the augmented reality method is an attractive visual display, which can display 3D objects that appear to exist in a real environment [10], [11]. The augmented reality method also has the advantage of being interactive because it uses markers to display 3D objects. Counseling with this method will increase the reasoning power and imagination of students because dental and mouth objects can be visualized into 3D images, so that extension material becomes more attractive, easy to remember and easy to implement.

\section{Method}

The first step is checking the status of oral hygiene using an index called the Simplified Oral Hygiene Index (OHI-S). OHI-S value obtained from the sum of the debris index and calculus index. Equation (1) and (2) To measure the debris and calculus index, it can be seen in equation (1) and (2). Debris and calculus score assessment as follows: Good, if the value is 0-0.6; Medium, if the value is 0.7-1.8; and Bad, if the value is 1.9-3.0. Moreover, OHI-S assessment as follows: Good, if the value is 0-1.2; Medium, if the value is 1.3-3.0; and Bad, if the value is 3.1-6.0.

$$
\begin{aligned}
& \text { Debris Index }=\frac{\text { Number of debris ratings }}{\text { Number of teeth examined }} \\
& \text { Calculus Index }=\frac{\text { Number of calculus assessment }}{\text { Number of teeth examined }}
\end{aligned}
$$

The next step, dental health counseling activities, consists of three materials. The first material is a function of deciduous teeth. The second material is the frequency and method of brushing teeth. And the last material is a source of healthy food.

An understanding of the role of primary teeth needs to be given to support the child's growth and development process. The role of parents is crucial in supporting this program at home because it can provide examples, encourage, remind and help children about the habit of brushing their teeth. Counseling information about healthy food for teeth also needs to be provided, so parents can provide healthy food at home and in preparing the children's supplies at school. Counseling activities using Android-based Augmented Reality (AR) technology. AR is expected to stimulate the curiosity of students to learn because it is accompanied by video animation/cartoon.

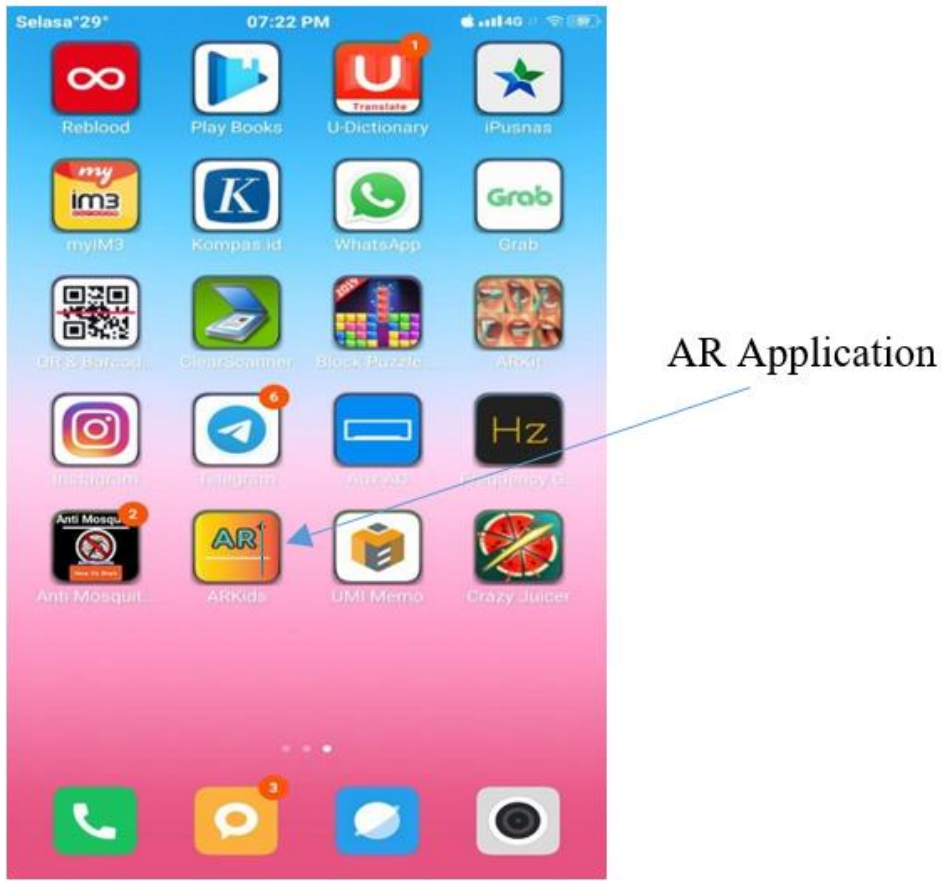

Fig. 1. AR Application with Android Based 


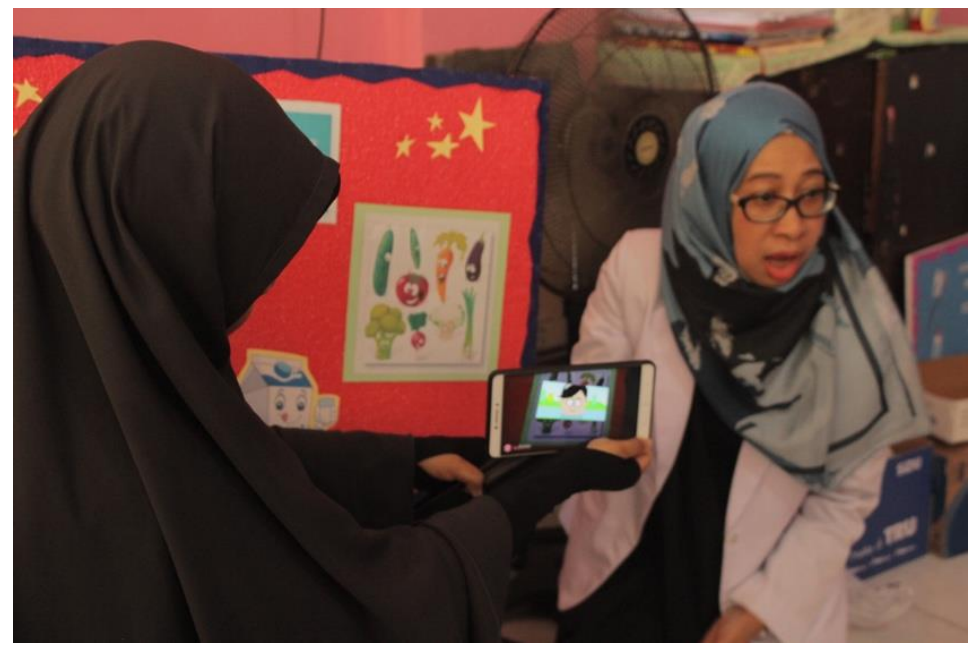

Fig. 2. AR Application Implementation

Toothbrush activity is the implementation of the extension phase of the teeth. Students will conduct a joint toothbrush using a brush and tooth given. Each student will be monitored one by one while being given examples by the counseling material that has been taught. Aside from school, tooth brushing must also be monitored by parents of students at home. The result of this program is expected to be a sustainable activity both at school and at home.

Teeth that are being treated will be given a lift (fillings) using Glass Ionomer Cement Fuji IX. The next step is giving TAF material to healthy teeth as well as teeth that have been capped (patched). The goal given TAF material is 4 namely 1 ) helps inhibit the occurrence of dental caries by providing tooth enamel protection so that it is more resistant to the demineralization process caused by acidic conditions in the oral cavity, 2) stimulates the remineralization process on the enamel surface, 3) inhibits the microbiological enzyme system which converts carbohydrates to acids in dental plaque, and 4) there is a bacteriostatic effect that inhibits bacterial colonization on the tooth surface. The procedure for Topical Application Fluor (TAF) is as follows:

- Teeth are cleaned with pumice paste and rubber cup.

- Teeth are isolated with cotton rolls.

- Teeth are dried with air spray, especially interproximal areas.

- Apply 2\% sodium fluoride solution to the teeth with a cotton pellet or micro brush.

- Dry for three minutes, and not eat, drink or gargle in one hour.

- Repeat all steps four times a month. Giving sodium fluoride four times can help prevent dental caries and last up to three years.

\section{Results and Discussion}

Augmented Reality Based Dental Education Activities are carried out four times in three months. These activities provide educational counseling to students, parents, and teachers about the importance of oral and dental health care. Activities that use instrument Augmented Reality (AR) is beneficial to facilitate teachers and parents to teach the habit of taking care of your teeth and mouth. After providing counseling to 50 students, ten teachers, and representatives of parents, then the monitoring carried out for 30 days. The results of this activity are 100 percent of students Nurul Falah brush their teeth every morning, which is visible through the control card.

The teachers have also installed the AR application to assist them in conducting the teaching process, which contains the importance of caring for teeth and how to choose healthy foods. 
The application of AR to educate students is beneficial in providing a different and memorable learning experience. AR technology can attract users, especially students [12], [13] to a new world so that it can have an impact on improving the quality of education more optimally. By involving several senses, AR becomes one of the technologies suitable for education [14]. In addition to providing counseling, the service lecturers also applied TAF for students. Provision of TAF can help prevent caries that occurs in children, for approximately six months.

\section{Conclusion}

Based on this study, it can draw several conclusions. Dental education for pre-school age needs to be done to prevent early damage to children's teeth. Then, activities counseling is equipped with a control card module, and dental care was given to teachers and parents of students. In addition, learning how to take care of oral health and choosing healthy foods using Android-based AR technology has an impact on students' habit of cleaning their teeth every day, and makes it easy for teachers to teach children to understand the importance of dental care.

Dental extension activities should get support from all elements, especially the school. Knowledge of how to care for teeth dramatically affects the growth and development of children, especially those from the lower middle class. A healthy tooth and mouth condition is needed so that all activities of the child are not disrupted. Finally, oral health helps children to meet their nutritional needs.

\section{Acknowledgment}

Our gratitude goes to the Directorate of Research and Community Service, Ministry of Research, Technology and Higher Education for providing financial assistance to the Community Service Stimulus in 2018. Hopefully what we have done can benefit our institutions, especially Universitas Muslim Indonesia in Makassar.

\section{References}

[1] M. H. Ahangar-Atashi, "Prevalence of Dental Malocclusions in Patients admitted to the Department of Orthodontics, School of Dentistry, Tabriz, in 2016," J. Contemp. Dent. Pract., vol. 18, no. 11, pp. 10341039,2017

[2] V. P. Singh and A. Sharma, "Epidemiology of Malocclusion and Assessment of Orthodontic Treatment Need for Nepalese Children," Int. Sch. Res. Not., vol. 2014, no. 768357, 2014.

[3] J. K. Baskaradoss, A. Geevarghese, C. Roger, and A. Thaliath, "Prevalence of malocclusion and its relationship with caries among school children aged 11-15 years in southern India," Korean J. Orthod., vol. 43, no. 1, pp. 35-41, 2013.

[4] R. Harris, A. D. Nicoll, P. M. Adair, and C. M. Pine, "Risk factors for dental caries in young children: a systematic review of the literature," Community Dent. Health, vol. 21, no. 1, pp. 71-85, 2004.

[5] M. Demers, J. M. Brodeur, P. L. Simard, C. Mouton, G. Veilleux, and S. Frechette, "Caries predictors suitable for mass-screenings in children: a literature review," Community Dent. Health, vol. 7, no. 1, pp. $11-21,1990$.

[6] T. M. de Carvalho and A. F. Miranda, "Preventive Orthodontics: Space Maintainers in the Early Loss of Deciduous Tooth-Clinical Case Report," EC Dent. Sci., vol. 10, pp. 143-148, 2017.

[7] D. E. Al Agili, "A systematic review of population-based dental caries studies among children in Saudi Arabia," Saudi Dent. J., vol. 25, no. 1, pp. 3-11, 2013.

[8] H. Elmunsyah, W. N. Hidayat, and K. Asfani, "Interactive learning media innovation: utilization of augmented reality and pop-up book to improve user's learning autonomy," J. Phys. Conf. Ser., vol. 1193, no. 1, 2019.

[9] S. Zheng, "Research on Mobile Learning Based on Augmented Reality," Open J. Soc. Sci., vol. 3, no. 12, p. 179, 2015. 
[10] M. M. Zarzuela, F. J. D. Pernas, L. B. Martínez, G. Ortega, and M. A. Rodríguez, "Mobile Serious Game using Augmented Reality for Supporting Children's Learning about Animals," Procedia - Procedia Comput. Sci., vol. 25, pp. 375-381, 2013.

[11]Á. Zsila, G. Orosz, B. Beáta, I. Tóth-király, and O. Király, "An empirical study on the motivations underlying augmented reality games : The case of Pokémon Go during and after Pokémon fever," Pers. Individ. Dif., 2017.

[12]D. McMahon, D.F. Cihak, and R. Wright, "Augmented reality as a navigation tool to employment opportunities for postsecondary education students with intellectual disabilities and autism," Journal of Research on Technology in Education., vol. 47, no. 3, pp.157-172, 2015.

[13] M. Akçayır, and G. Akçayır, "Advantages and challenges associated with augmented reality for education: A systematic review of the literature" Educational Research Review., vol. 20, pp. 1-11, 2017.

[14] R.M. Yilmaz, "Educational magic toys developed with augmented reality technology for early childhood education," Computers in Human Behavior., vol. 54, pp.240-248, 2016. 